\title{
Az Európa Tanács szerepe Kelet-Közép-Európa demokratikus átalakulásában - Az Európai Unió elôszobája
}

\section{Tóth-Ferenci Adrienn}

https://doi.org/10.47707/Kulugvi_Szemle.2021.2.02

Összefoglalás': A hatékony multilateralizmus az elmúlt élvekben megkérdôjjelezódött. A hidegháború végén és a közép-kelet-európai rendszerváltás elsö éveiben mindazonáltal nagy volt a várakozás a multilaterális szervezetek irányában. Az Európa Tanács Miniszleri Bizoltságának 2021 májusa és novembere közölti második ma gyar elnöksége időszerüvé teszi az Európa Tanács közép-kelet-európai politikai átalakulásban játszott történelmi szerepének áttekintését is. A tanulmány különös figyelmet szentel a szervezetnek a 90-es évek új kihivásai kezelése érdekében végrehajtoll intézményi megújulására, bemulatja és érlékeli az Európa Tanács emberi jogi rendszerének föbb elemeit. A második magyar elnökség ugyanis többek közöı arra törekszik, hogy az Európa Tanács aranykora" idején kialakitoll mechanizmusok közül a kisebbségvédelem területén kialakitotı felülvizsgálati struktúra tovább erösödjön.

Kulcsszavak: rendszerválıás, Közép-Kelet-Európa, Európa Tanács, emberi jogi rendszer, intézményi reform, magyar elnökség

Abstract: Effective multilateralism has been challenged in recent years. However, expectations were high towards multilateral institutions at the end of the Cold War and during the first years of the regime change in the Central and Eastern European countries.

A szerző a Budapesti Corvinus Egyetem Nemzetközi Kapcsolatok és Politikatu dományi Doktori Iskolájának doktorjelöltje, a Külgazdasági és Külügyminisztérium szomszédságpolitika fejlesztéséért felelős miniszteri biztosi kabinetének főosztályvezetője. 
The Hungarian Presidency of the Committee of Ministers between May and November 2021 makes the overview of the historical role of the Council of Europe in the political transition of Central Eastern Europe very topical. This study has a special focus on the institutional renewal of the Organisation to fulfil its potential in addressing the main challenges of the 1990s. The paper also aims to present and evaluate the main elements of the human rights regime in the Council of Europe. The second Hungarian Presidency shall endeavour inter alia to further strengthen the supervisory scheme developed in the "Golden Age" particularly in the field of national minority protection.

Keywords: democratic transition, Central Eastern Europe, Council of Europe, human rights regime, instilutional reform, Hungarian Presidency

\section{Bevezetés}

Az 1949-ben Londonban alapított Európa Tanács az "Alapító Atyák" által elképzelt, II. világháború utáni európai intézményrendszer első elemét képezte. Abból a meggyőződésből, hogy az igazságszolgáltatásra és nemzetközi együttműködésre épülő béke elengedhetetlen az emberi társadalom és civilizáció megőrzéséhez (Európa Tanács Alapokmánya, Preambulum, 1949), a szervezet elsődleges célját a tagok közötti nagyobb egység megteremtésében, az európai közös örökség elveinek és eszményeinek megvalósításában és megőrzésében, illetve a gazdasági és társadalmi fejlődés előmozdításában határozták meg. Bármely európai állam csatlakozhatott az Európa Tanácshoz, feltéve, hogy elfogadta a jogállamiság elveit és az emberi jogok és alapvető szabadságjogok minden, joghatósága alá tartozó ember számára történő biztosítását (Európa Tanács Alapokmánya).

2 Winston Churchill, Konrad Adenauer, Robert Schuman, Paul Henri Spaak, Alcide de Gasperi, Ernest Bevin. Lásd az Európa Tanács honlapján. Letöltve: 2021. március 5. https://www.coe.int/en/web/about-us/founding-fathers 


\section{Külïgyi Szemle}

1990-re a fokozatosan mélyülő európai integráció (Barth, Bijsmans 2018) önreflexiós folyamatokat indított el az Európa Tanácsban, szükségessé vált a szervezet Európai Közösségekhez ${ }^{3}$ képest történő önmeghatározása. ${ }^{4}$ Bár a maastrichti szerződéssel5 létrejövő Európai Unió nem teljesen vethető össze az Európa Tanáccsal mint kormányközi szervezettel (Hlavac 2010), mégis szükségessé vált a két európai intézmény hatáskörének egymáshoz képest való meghatározása (Joris, Vandenberghe 2008). Ezt a munkamegosztást indokolta az egyre hangsúlyosabbá váló együttműködés (Official Journal of the European Communities, 1987) illetve az intézményesülő „négy résztvevős” találkozók is (Nyilatkozat az Európa Tanács jövőbeni szerepéről az európai intézményrendszerben, 1989). A két európai szervezet közötti kapcsolat azonban külön elemzést érdemel, ennek vizsgálata nem képezi jelen tanulmány tárgyát.

Az Európa Tanács jelenleg ismert intézményi arculata a kelet közép-európai ${ }^{7}$ (Herczeg, 1998) rendszerváltás előestéjén még nem alakult ki. A történelmi lehetőség az európai államok egyesítésére, és az európai közös örökség demokratikus elveinek az egész európai kontinensre való kiterjesztésére a Berlini fal leomlását és a Szovjetunió összeomlását követően érkezett el. Mind az Európa Tanács (ET) kormányközi döntéshozó szerve, a Miniszteri Bizottság (MB), mind parlamenti fóruma, a Parlamenti Közgyűlés (PKGY) egyetértett abban, hogy az Európa Tanács megfelelő keretet biztosít Közép-és

3 1993-ig az Európai Szén- és Acélközösségnek, az Európai Gazdasági Közösségnek és az Európai Atomenergia Közösségnek az összefoglaló neve (Kende 1995. 124-143).

4 A Szerző személyes véleménye.

5 Az 1992. február 7-én aláirt maastrichti szerződés 1993. november 1-jén lépett hatályba.

6 A „quadripartite” találkozókat az 1989. május 5-i küilügyminiszteri találkozón elfogadott politikai nyilatkozat intézményesítette. 8. pontja szerint a „quadripartite” találkozókat a Miniszteri Bizottság soros elnöke, az ET-főtitkár, valamint az Európai Közösségek Tanácsának elnöke és az Európai Bizottság elnöke részvételével tartják.

7 Kelet-Közép-Európa alatt, Herczeg Géza történelmi régiója nyomán, jelen tanulmány Lengyelországot. Magyarországot, Csehországot és Szlovákiát, vagyis a V4-eket érti, de Szlovénia és Horvátország, illetve Románia is köthető hozzá. 
Kelet-Európa államai számára az európai struktúrához való teljes jogú csatlakozásra, illetőleg az ET hatékonyan képes hozzájárulni Európa politikai, jogi, szociális és kulturális dimenziójának kiterjesztéséhez (PACE recommendation 1990, 1124). Az új küldetéshez azonban új eszközökre volt szüikség. Az 1990-es években kialakított, előremutató me chanizmusok pedig mára meghatározzák az Európa Tanács arculatát. ${ }^{8}$

\section{Az Európa Tanács emberi jogi mechanizmusai a kelet-európai rendszerváltás elótt}

Egy Európa helyét és szerepét a felemelkedő két globális szuperhatalom, az Amerikai Egyesült Államok és Szovjetunió között biztosító páneurópai szervezet létrehozásának gondolata már az I. világháborút követően megjelent. Azonban a nemzetállamok, főként pedig a XIX. század nagyhatalmai közötti versengés a vezető szerep elnyeréséért, akkor megakadályozta a kontinens egyesítését. A II. világhá ború tragikus eseményei és fájdalmas tapasztalatai ébresztették csak rá Európa nemzeteit, fóleg a korábbi nagyhatalom Nagy-Britanniát és Franciaországot arra, hogy az egyeduili esély az elvesztett politikai befolyás visszaszerzésére a föderális megközelítés követése lesz (Gazdag, Kovács 1999, 31-48.). Számos elvi és gyakorlati vitát követően az Európa Tanácsban megtestesüilő egyuittmúködési modell egyfajta kötelező átmenetet képez a többi európai és transzatlanti együittmúködési formához képest (Mezei, 1999, 49-51.). A szervezet alapítói az Európa Tanácsban az Európa-építési folyamat megtes tesülését látták, a kormányközi együttmúködési kereteken túlhaladva az Európa Tanács létrehozásával a II. világháború utáni Európa ér tékközösségét kívánták létrehozni (Mezei et al. 1999, 51.).

Az értékközösség kialakításának célját szolgálta az Európa Tanács által módszeresen létrehozott emberi jogi egyezményrendszer, melyhez elősorban az emberi jogi alapegyezménye ${ }^{9}$ és annak

8 A Szerző véleménye.

9 Emberi Jogok Európai Egyezménye (EJEE), ETS 005, Róma, 1950. november 4. 


\section{Külïgyi Szemle}

kiegészítő jegyzőkönyvei, de bármely más, emberi jogi vonatkozású jogi norma, így pl. a kínzás megelőzéséről szóló egyezmény ${ }^{10}$, vagy akár a szociális jogokat biztosító egyezmény" is tartozott.

A szervezet a normaalkotási tevékenység kiegészítéseként szigorúan ellenőrzi a vállalt kötelezettségek végrehajtását és a tagállamok ET-normák teljesítése területén tett előrehaladását is. Azáltal azonban, hogy a kelet-európai bóvítés révén új szakértő testületeket hozott létre az új tagállamok európai normákkal való minél szélesebb körủ megfelelésének segítésére, az Európa Tanács tulajdonképpen háromszoros célkitủzést teljesít. A normák és sztenderdek kidolgozása és számonkérése mellett célzott támogatási programokkal, intenzív párbeszéd és szakmai támogatás révén a végrehajtás nemzeti szintủ elősegítése is a küldetésében szerepel. Ez utóbbi pillér kapott hat hatós támogatást, és ment át gyökeres átalakításon az 1990-es évek kelet-európai politikai változásai következtében. Tekin tettel azonban arra, hogy a kelet-európai tagjelölt országok többségénél a szervezet tulajdonképpen megelőlegezte a teljes tagságot az alapvető kritériumok teljesítése esetén anélküil, hogy szigorúan számonkérte volna a demokratikus intézményrendszer kiépítésében tett előrehaladást, lényegében előrevetítette az emberi jogi normák végrehajtását a későbbiekben érő komoly kihívásokat.

\section{Új emberi jogi intézmények létrehozása 1990 után}

A fentiekben kifejtett körüilmények és megfontolások következ tében az Európa Tanács tehát számos új intézmény létrehozá sáról döntött annak érdekében, hogy segítse a tagsági kérelmet benyújtott kelet-közép-európai államok európai normák szerinti

10 Egyezmény a kínzás és az embertelen vagy megalázó büntetések vagy bánásmód megelőzéséről Strasbourg, 1987. november 26.

11 Európai Szociális Charta, ETS 035. Torinó, 1961. október 18. 
demokratikus átalakulását. A kelet-közép-európai államok számára az ET-tagság komoly lehetőséggel bírt, a első lépést jelent vén az euroatlanti integrációs folyamatban, hiszen mára a kelet közép-európai történelmi régió (Herczeg et al. 1998) mindegyik állama tagjává vált az Európa Uniónak is. ${ }^{12}$

\section{Emberi Jogok Európai Birósága}

Bár az Emberi Jogok Európai Bírósága (EJEB) az Emberi Jogok Európai Egyezménye 19. cikkelye nyomán már 1959-ben ${ }^{13}$ lét rejött, az állandó Bíróság csupán az EJEE 11. kiegészítő jegyzőkönyvének hatálybalépésétől kezdve, 1998-tól működik. A Bíróság által befogadható ügyeket az egyezmény rögzíti, államközi ügyekkel és egyéni panaszokkal is foglalkozik az egyezményben és kiegészítő jegyzőkönyvekben fogalt elfogadhatósági kritéri umok alapján. ${ }^{14}$ Legismertebb elfogadhatósági feltétele a hazai jogorvoslati lehetôségek kimerítése, illetve a kérelemnek a hazai jogorvoslati lehetôségek kimerítésérỏl szóló végleges határozat tól számított hat hónapon belüli benyújtása az EJEB-hez. Utóbbi feltételt a bíróság ügyterhének csökkentését célzó bírósági reform keretében már módosítja az EJEE 2013-ban aláírásra megnyitott 15. kiegészítő jegyzőkönyve, azonban annak hatálybalépéséhez az EJEE összes részes államának, vagyis az ET mind a

12 Magyarország 1990. november 6-án csatlakozott az Európa Tanácshoz 24. tagállamként, és elsőként a kelet-európai régióból, megelőzve Lengyelországot (1991), Bulgáriát (1992), Észtországot, Litvániát, Szlovéniát, Csehországot, Szlová kiát, Romániát (1993), Lettországot, Ukrajnát, Albániát, Észak-Macedóniát (1995). Horvátországot, Oroszországot (1996), Bosznia-Hercegovinát (2002), Szerbiát (2003) és Montenegrót (2007).

13 Az ET Parlamenti Közgyúlésének elődje, az ún. Tanácskozó Gyúlés (Consultative Assembly) a Bíróság első tagjait 1959-ben választotta meg, és a Bíróság első ülésszakát 1959 februárjában tartotta. The Court in Brief. https://www.echr.coe.int/ Documents/Court_in_brief_ENG.pdf

14 EJEE 35. cikk. 


\section{Külïgyi Szemle}

47 tagállamának ratifikálása szükséges. A szóban forgó kiegészí tỏ jegyzőkönyvhöz eddig 46 tagállam csatlakozott, a reformin tézkedés hatálybalépésére mindaddig nem kerül tehát sor, amíg a fennmaradó egy tagállam nem ratifikálja az egyezményt.

Az EJEB ítéleteinek végrehajtása az egyezmény 46. cikke értelmében minden szerződő fél számára kötelező, az ítéletek végrehajtását a Miniszteri Bizottság feladata ellenőrizni (EJEE 46. cikk 2. pont).

A Miniszteri Bizottság rendszeresen felülvizsgált döntése alapján $^{15}$ az ítéletvégrehajtás $\mathrm{MB}$ általi ellenőrzését küilön erre a célra felállított szervezeti egység koordinálja. Ez a főosztály szervezi a negyedévente megrendezésre kerüiő emberi jogi formációjú miniszteri bizottsági, ismertebb nevén CMDH-üléseket (általában március, június, szeptember, december első heteiben) ${ }^{16}$. Az itéletvégrehajtási Főosztály (EXEC) amellett, hogy összeállítja a CMDH-ülések napirendjét, naprakész háttéranyagokat és értékelő elemzéseket is készít a napirenden szereplő ügyek végrehajtásának állapotáról, a meghozott nemzeti intézkedésekrôl, a CMDH által elfogadott korábbi határozatokról, hogy ezzel is segítse a Miniszteri Bizottságot az ítéletek végrehajtásának hatékony ellenőrzésében. A tagállamok a végrehajtás állapotáról ún. cselekvési tervekben (action plan) számolnak be. A szüikséges egyéni vagy általános intézkedések meghozatalát, vagyis a bírósági ítélet teljesítését követően az MB határozatban (resolution) zárja le a vizsgálatot. Tekintettel arra, hogy a Miniszteri Bizottságot a 47 tagállam kormányzati képviselői alkotják, a bírósági ítéletetek végrehajtása nem ritkán túlmutat a jogi természetủ eszmecserén, és számos esetben politikailag túlfütött vitákba torkollik. Ilyen esetben nem feltétlenül nyújt támpontot az EXEC által elkészített, tárgyszerú jogi elemzés; a küldöttségek politikai megbízás alapján foglalnak

15 Többek között a 2016. március 30-ai határozat szabályozza az itéletvégrehajtást felügyelő szervezeti egység feladatkörét. GR-H(2016)2-final, 30 March 2016.

16 A szerző saját tapasztalata a CMDH (Comité des Ministres Droits de l'Homme) ülésein való személyes részvétel alapján 2011-2016 között. 
állást. Kiváló példa erre a Ciprus kontra Törökország ${ }^{17}$ államközi ügy, melyben a Bíróság 2001-ben hozott ítéletet, végrehajtásának felülvizsgálata pedig három fejezet esetében a mai napig nincs lezárva. Sőt, a CMDH legutóbbi, 2021. márciusi ülésén azt a döntést hozta, hogy az államközi ügy bizonyos aspektusainak vizsgálatát csak egy év múlva, 2022 márciusában folytatja. ${ }^{18}$

Bár az ítéletek végrehajtása minden, az EJEE-hez csatlakozott tagállam számára kötelező, a felülvizsgálat során a Miniszteri Bizottság korlátozott eszközökkel rendelkezik a végrehajtás ki kényszerítésére. A határozatok, ideiglenes határozatok (interim resolution), főtitkári levél és közvetítés szemmel láthatóan nem hoznak áttörést a politikailag érzékeny kérdésekben. A helyzet fonákja éppen az, hogy ahol már fótitkári közbenjárásra van szükség, vajmi kevés esély kínálkozik a sikeres közvetítésre, hi szen nyilvánvalóan politikai megfontolások húzódnak a nem tel jesítés mögött. De nem csupán az államözi ügyek azok, ahol egy tagállam megmakacsolhatja magát. Az is általánosító közkeletű tévedés, hogy az ítéleteket csupán a nem szilárd demokratikus berendezkedésű államok vonakodnak végrehajtani. A Hirst kontra Egyesült Királyság ügyben a strasbourgi Bíróság a fogvatar tottak szavazati jogának biztosítását várta az alperes államtól (respondent state), a párbeszéd pedig 13 éven át zajlott. Végül a hasonló jogsérelemmel beérkezô ügyek számának növekedé se, illetve a nemzeti parlamentnek az MB által biztosított szé leskörű mérlegelési hatásköre (margin of appreciation) vezetett eredményre, mely végül az ítélet végrehajtása érdekében hozott brit intézkedéseket elegendőnek értékelte, és 2018 decemberében lezárta az ïgyet. ${ }^{19}$ A Miniszteri Bizottságnak tehát nincs tényleges

17 Press release issued by the Registrar, Judgment in the case of Cyprus v. Turkey, https:// hudoc.echr.coe.int/eng-press\#\{\%22itemid\%22: \%22003-68489-68957\%22\}\}

18 CM/Del/Dec(2021)1398/H46-32, Cyprusvs Turkey, VarnavaandOthersvs Turkey, https:/ search.coe.int/cm/Pages/result_details.aspx?ObjectID=0900001680alb36d

19 Five cases against the United Kingdom, CM/ResDH(2018)467. https://search. coe.int $/ \mathrm{cm} /$ Pages/result_details.aspx?ObjectID=09000016808feca9 


\section{Külïgyi Szemle}

eszköze a nem teljesítés szankcionálására. A legerősebb jelzés az EJEE 46. cikk 4. pontjának alkalmazása, amely az ET és az ítéletvégrehajtást közelről és aktívan követő civil szervezetek terminológiájában egyenlő a kötelezettségszegési eljárással. Ebben az esetben a Miniszteri Bizottság formálisan felkéri a Bíróságot annak eldöntésére, hogy az alperes állam valóban elmulasztotta-e az ítéletvégrehajtással összefüggő egyezményes kötelezettsége teljesesítését. Erre eddig az EJEB és a CMDH történetében egyszer adódott példa, amikor a Miniszteri Bizottság Azerbajdzsán esetében alkalmazta a kötelezettségszegési eljárás megindítását 2017 decemberében (CMDH Interim Resolution CM/ResDH(2017)429, 2017).

\section{Rasszizmus és Intolerancia Elleni Európai Bizollság (ECRI)}

A Rasszizmus és Intolerancia Elleni Európai Bizottság egy olyan emberi jogi monitoringmechanizmus, amely a faji, etnikai, nemzeti származási, a bőrszín-, az állampolgárság-, a vallás-, és a nyelvi alapú megkülönböztetéssel, az idegengyúlölet, antiszemitizmus és intoleracia eseteivel foglalkozik (ECRI's Mandate). A bizottság létrehozásáról az Európa Tanács tagállamainak állam-és kormányfői elsỏ csúcstalálkozójuk alkalmával, 1993-ban, Bécsben hoztak döntést (Vienna Declaration and Action Plan, CoE Summit, Vienna, 1993). A csúcstalálkozóra nem véletenül ekkor került sor. Annak összehívása mögött nem csupán a közös normák és elvek alapján újraegyesülő Európa eszméje húzódott meg, hanem a párhuzamosan zajló délszláv háború elrettentő példája is. Az újraéledő agresszív nacionalizmus, és annak a nemzeti kisebbség vonatkozásában is jelentkező katasztrofális következményei rádöbbentették az európai vezetőket arra, hogy nemcsak a békés európai építkezés lehet veszélyben. Jugoszlávia szétesése, és az ottani konfliktus eszkalálódása más régiókra is komoly politkai, geopolitikai veszélyeket jelent (Vienna Declaration and Action 
Plan, 1993). Ez a felismerés vezetett egy kormányközi szakér tői bizottság létrehozásához, amely felügyeli a rasszizmus, idegengyűlölet, antiszemitizmus és intolerancia elleni jogszabályalkotást, a nemzeti politikát és egyéb intézkedéseket a tagállamokban. A bécsi csúcstalálkozó akcióterve felhatalmazta az új testületet arra, hogy általános irányelveket fogalmazzon meg (general policy recommendation). Az állam- és kormányfők második, strasbourgi csúcstalálkozója megerősítette az ECRI jogosítványait 1997-ben (Strasbourg Declaration and Action Plan, 1997). Az ECRI Statútumának elfogadására végül 2002-ben, a Parlamenti Közgyúlés szélsőséges mozgalmak veszélyeiről szóló, 2000-ben elfogadott ajánlását (PACE recommendtion 1438 (2000)) követően kerüilt sor. A statútum rögzíti a bizottság man dátumát, valamint országmonitoringgal kapcsolatos és normaal kotó tevékenységét, melynek alapján ötéves ciklusokban ellenőriz évente 9-10 ET-tagállamot. Az ECRI létehozása óta 16 tematikus irányelvet fogadott el, és kiegészíti az Európa Tanács nemzeti kisebbségvédelmi monitoringtevékenységét.

\section{Emberijogi bizlos}

A 90-es évek nagy horderejủ változásai és az európai társadal makat érő kihívások következtében került sor az ET-tagállamok állam- és kormányfőinek második csúcstalálkozójára 1997-ben Strasbourgban (Final Declaration, Second Summit). A második csúcstalálkozó alkalmával egy olyan cselekvési terv kidolgozására került sor, amely a demokratikus stabilitás megerôsítése céljával olyan területeket azonosított be, ahol látványos eredményekre volt kilátás. Így a strasbourgi cselekvési terv az emberi jogok, szociális kohézió, állampolgári biztonság, demokratikus értékek és kulturális sokszínūség területén fogalmazott meg javaslatokat (Action Plan, 1997). Az emberi jogi biztos hivatalának létrehozása 


\section{Külïgyi Szemle}

is ezek között a javaslatok közöt szerepelt ${ }^{20}$, létrehozásáról végül a Miniszteri Bizottság az első magyar elnökség idején, a Budapes ten megrendezésre került 104. küilügyminiszteri értekezlet során döntött (CM Resolution (99) 50). A budapesti külügyminiszeri értekezlet során nemesak az emberi jogi biztos intézményének létrehozásáról született döntés. A szervezet alapításának 50. évfordulójával egybeeső magyar soros elnökség alkalmával a külügyminiszterek a budapesti nyilatkozatban megerősítették elkötelezettségüiket az Európa Tanács mint Európát újra egyesíteni képes intézmény emberi jogi mechanizmusainak alkalmazása és az emberi jogok primátusa iránt (Budapest Declaration 1999).

Az emberi jogi biztosi hivatalt létrehozó határozat értelmében a biztos széleskörú jogosítványokkal rendelkezik az emberi jogi tudatosság és oktatás előmozdítása, az emberi jogok védelmét és a jogsértések megelőzését célzó felvilágosítás és tanácsadás, a nemzeti emberi jogvédő intézmények tevékenységének elősegítése, a tagállami emberi jogi szabályozások és gyakor lat hiányosságainak beazonosítása, az emberi jogi sztender dek végrehajtásának elősegítése és bármely, az emberi jogokkal összefüggű témával kapcsolatos jelentéstétel területén (CM Resolution (99) 50).

Az emberi jogi biztos hivatala nem igazságügyi intézmény, vagyis egyéni panaszokkal nem foglalkozik, de módjában áll kö vetkeztetéseket megfogalmazni vagy állampolgárok sérelmé re elkövetett emberi jogsértések nyomán széleskörú kezdeményezéseket elindítani. Az emberi jogi biztos számos nemzetközi és nemzeti intézménnyel múködik együtt, így az ENSZ és szakosított intézményei, az Európai Unió, EBESZ vagy vezető emberi jogi civil szervezetek, egyetemi szféra és think tankek is a partnerei között

20 A jelenlegi emberi jogi biztost a Parlamenti Közgyűlés 2018. január 25-én választotta meg. A Bosznia-Hercegovinából származó Dunja Mijatović 2018. április 1-jén foglalta el hivatalát és kezdte meg hatéves mandátumát. A jelenlegi biztos negyedik a hivatalban a lett Nils Muižnieks (2012-2018), a svéd Thomas Hammarberg (2006-2012) és a spanyol Alvaro Gil-Robles (19992006) után. 
szerepelnek (Az emberi jogi biztos mandátuma, 1999). Az emberi jogi biztos mandátuma hármas célkitűzés alapján az országlátogatásokra és nemzeti hatóságokkal, civil szervezetekkel való párbeszédre, tematikus jelentéstételre, az emberi jogok alkalmazásának végrehajtását szorgalmazó tanácsadásra, valamint felvilágosító tevékenységre épül (The Commissioner, CoE).

A biztos tematikus tevékenysége az új kihívások számszerū nö vekedésével fokozatosan bővül. A klasszikus emberi jogi kérdések, mint a véleménynyilvánítás szabadsága, a sérülékeny társadalmi csoportok védelme vagy az esélyegyenlőség mellett, olyan területek is előtérbe kerültek, mint a mesterséges intelligencia emberi jogi aspektusai vagy a pandémia, illetve a gazdasági helyzet emberi jogi vetületei.

\section{Joggal a Demokráciáért Európai Bizoltság (Velencei Bizottság)}

Ha csak egy ET-intézményt kellene kiemelni, amely a legnagyobb mértékben járult hozzá a kelet-európai országok demokratikus átalakulásához, és a legismertebb, legelismertebb intézmények között szerepel, az kétségkívül a Velencei Bizottság lenne. Hírneve túlszárnyalja az ET-térség határait is, alkotmányozási kérdésekben máig a legfőbb hivatkozási pont. Az Európai Unió is épít a Velencei Bizottság tevékenységére, egyrészt speciális státusszal rendelkezik a Velencei Bizottságban, másrészt számos esetben hivatkozik a véleményére. A Velencei Bizottság korábbi német tagja, Wolfgand Hoffman-Riem véleménye szerint a testület egyenesen az Európai Unió döntéshozatalára is hatással lehet, különösen azóta, hogy az Európai Bizottság számos alkalommal saját tevékenysége szolgálatába állította a Velencei Bizottságot (Hoffmann-Riem²1, 2014. 584.).

21 Wolfgang Hoffmann-Riem német jogászprofesszor, a Német Szövetségi Alkotmánybíróság korábbi bírája és a Velencei Bizottság korábbi német tagja. 


\section{Külïgyi Szemle}

La Pergola ${ }^{22}$, olasz jogászprofesszor elképzelése nyomán a Velencei Bizottság létrehozására végül az olasz küllügyminiszter tett javaslatot Velencében, az 1989. március 31-április 1-jén meg rendezésre került Joggal a demokráciáért alkotmányozó konferencián. ${ }^{23}$ A közép-és kelet-európai államokban a berlini fal leomlása után egyre sürgetőbbé vált az igény a demokratikus alkotmányozási folyamat támogatására, ezért a Miniszteri Bizottság 1990. január 19-20-án, szintén Velencében megrendezésre került konferenciáján úgy döntött, hogy részegyezmény formájában hozza létre az új bizottságot (Schnutz Dürr, 2010).

Bár manapság már a Velencei Bizottság tevékenysége az egyik legsikeresebbnek és legismertebbnek tekinthető, kezdetben nem minden tagállam volt lelkes a kezdeményezés hallatán, és nem is volt mindenki hajlandó a részegyezményhez való csatlakozásra. Egyes tagállamok attól féltek, hogy a Bizottság hozzájárul a szakosított bíróságok elterjedéséhez az alkotmányos felülvizsgálati jogkörrel rendelkező legfelsőbb bíróságokkal szemben (Schnutz Dürr, 2010).

2010-ben készült, a Velencei Bizottságot bemutató munkájá ban Schnutz Dürr arra is felhívta a figyelmet, hogy az alkotmányjog területén való együttmúködés egyáltalán nem volt egyértelmú egy kormányközi szervezet keretein belül. Az alkotmányjog szüikségszerủen közel áll az állami szuverenitást érintő kérdéskörökhöz, és olyan érzékeny aspektusokkal is foglalkozik, mint a hatalmi ágak, a végrehajtói és törvényhozói hatáskör szétválasztása. Ezek a körüimények indokolták azt, hogy nem alakult ki konszenzus a Bizottság létrehozásának szükségességével kapcsolatban, így az csupán részegyezmény formájában jött létre, és kezdetben az ET akkori 23 tagállama közül mindössze 18 csatlakozott a kezdeményezéshez a Miniszteri Bizottság határozata alapján (1990 (CM Resolution (90) 6).

22 Antonio Mario La Pergola, olasz jogtudós, föügyész, később a közösségi politika koordinálásáért felelős miniszter (1987-1989) az Európai Unió Bíróságának bírája (1994-2006).

23 Final Declaration of the Conference "Democracy through Law" (Velence, 1989. március 31- április 1.) 
A Joggal a Demokráciáért Európai Bizottság, amely statútuma szerint az Európa Tanács alkotmányozási kérdésekben illetékes konzultatív testületeként kezdte meg tevékenységét, végül székhelye után Velencei Bizottságként vált általánosan is mertté. A bizottság mandátuma alapján az ET tagállamaival és harmadik országokkal24, fỏként közép-kelet-európai államokkal múködött együtt alkotmányozási, törvényhozási és igazgatási elvi és gyakorlati kérdésekben egyrészt a demokratikus intézmények hatékonysága és erősítése, másrészt a jogállamisági elv érvényesülésének elősegítése érdekében (Appendix to Resolution (90) 6, Statute 1990).

Bár a bizottság elismertségének köszönhetően mára meg lehetősen kiszélesedett a tevékenységi területe - alapjogi kérdésekben, a demokratikus intézményekkel és a jogállamisággal összefüiggỏ törvényalkotást, igazságszolgáltatási reformot vagy nemzeti kisebbségi jogokat érintő kérdéskörökben is kikérik a véleményét - a Velencei Bizottság tevékenységéről szóló 2019. évi jelentés a testület elsődleges tevékenységi köreként továbbra is az alkotmányozási tanácsadást jelöli meg, amelyet a testület vélemény formájában készít el. Ahogy az éves jelentés is kiemeli, de a Statútum 3. cikkely 2. pontja rögzíti, ilyen kérést az érintett tagállam, vagy az ET különböző szervei, a Parlamenti Közgyúlés, a Miniszteri Bizottság, a Helyi vagy Regionális Önkormányzatok Kongresszusa (CLRAE), a fötitkár vagy a VB tevékenységében részt vevő más nemzetközi szervezetek és testületek fogalmazhatnak meg. Az éves jelentés arra is felhívja a figyelmet, hogy a VB-vélemények formailag ugyan nem bírnak jogi kötőerővel, mégis hatással vannak a vonatkozó ország jogalkotására, hála a bizottság hírnevének, függetlenségének, pártatlanságának és nemzteközi presztízsének. A vélemény elfogadását követően ráadásul a bizottság kész továbbra is segíteni az érintett tagállamot, amíg az alkot mány vagy más, szóban forgó törvény elfogadásra nem kerül.

24 A statútum elfogadásakor még egyetlen kelet-közép-európai állam sem volt tagja az Európa Tanácsnak. 


\section{Külïgyi Szemle}

2002-ben, miután az Európa Tanács minden akkori tagja csat lakozott hozzá, a bizottság kiterjesztett részegyezménnyé alakult át, vagyis lehetővé vált nem európai országok csatlakozása is. 2019-ben 62 teljes jogú tagot számlál és 13 egyéni entitás formálisan is kapcsolódik a tevekénységéhez (Annual report 2019).

\section{Nemzeti kisebbségvédelem az Európa Tanácsban}

A nemzeti kisebbségi kérdéskör változó intenzitással ugyan, de a kezdetektől fogva az Európa Tanács tevékenységének homlokterében áll. A Palamenti Közgyúlés elődjeként az ún. Tanácskozó Gyúlés ${ }^{25}$ már 1949-ben javasolta a Miniszteri Bizottság számára egy olyan egyezmény kidolgozását, amely az ENSZ Közgyülés által 1948. december 10-én elfogadott Emberi Jogok Egyetemes Nyilatkozatában ${ }^{26}$ foglaltakra hivatkozva kollektív garanciát nyújt minden állampolgára számára a jogok és alapvető szabadságjogok gyakorlásához (PACE recommedation 38 (1949). Ennek eredményeként született az Egyezmény az emberi jogok és alapvető szabadságok védelméről ${ }^{27}$, de preambuluma szerint ez csak az első lépés volt az Emberi Jogok Egyetemes Nyilatkozatában foglalt egyes jogok kollektív érvényesüléséhez. A Parlamenti Közgyűlés 1960-ban javaslatot tett a Miniszteri Bizottságnak az EJEE második kiegészítő jegyzőkönyve kidolgozására, amely az első jegyzőkönyv által nem említett bizonyos polgári és politikai jogokról szól (PACE recommendation 234 (1960)). A PKGY ugyanezen ajánlása szövegszerú javaslatot is tett egy olyan cikkely megfogalmazására, mely kimondja a törvény előtti egyenlőséget, és tiltja a diszkriminációt többek között nemzeti hovatartozás és nemzeti kisebbséghez tartozás alapján is.

\footnotetext{
25 Consultaive Assembly

26 Az Emberi Jogok Egyetemes Nyilatkozata https://www.ohchr.org/en/udhr/ documents/udhr_translations/hng.pdf

27 Emberi Jogok Európai Egyezménye (EJEE). ETS 005, Róma, 1950. november 4.
} 
1961. évi 285. számú ajánlásában a PKGY emlékeztet arra, hogy az Emberi Jogi Egyezmény 14. cikkelye ugyan biztosít némi védelmet a nemzeti kisebbségek számára a diszkriminációval szemben, ugyanakkor szüikség van a nemzeti kisebbségek kollektív érdekeinek az államok alapvetô érdekeinek figyelembevételével történő biztosítására is. Ezért olyan szöveget javasol a második kiegészítő jegyző könyvbe, amely kitér a nemzeti kisebbségek azon jogára, hogy közös ségként, a közrend tiszteletben tartásával gyakorolhassa saját nyelvét és kultúráját, iskolát hozhasson létre, ahol a maga választotta nyelven kap oktatást, és azon a nyelven gyakorolhatja vallását. Az ígéretes pró bálkozásokat végül az Emberi Jogi Bíróságnak a belga nyelvi ügyben hozott 1968-as ítélete ${ }^{28}$ akasztotta meg, melynek következtében az illetékes szakértői bizottság is arra a konklúzióra jutott 1973-ban, hogy nem szüikséges a kisebbségek jogairól külön kiegészítő jegyzőkönyv kidolgozása (FCNM Explanatory report, 1995, 1.).

Fentiekhez hasonló kezdeményezések születtek a kisebbségi nyelveket és azokat használó közösségek védelmére is. A Tanács kozó Gyúlés 1957-ben és a Parlamenti Közgyúlés 1961-ben is ${ }^{29}$ fel szólított az Emberi Jogi Egyezmény kisebbségi jogokat, kisebbségi kultúrát és nyelvet védő kiegészítésére (ECMRL Explanatory report, 1992, 1.). A Parlamenti Közgyúlés 1981. évi 928-as ajánlása felhívta a figyelmet a kisebbségi nyelvű oktatási és kulturális problémákra, és ugyanebben az évben az Európai Parlament is elfogadott egy állásfoglalást ebben a kérdésben. Mindkét dokumentum arra a következtetésre jutott, hogy szüikség van a regionális vagy kisebbségi nyelvek és kultúra védelmét célzó charta kidolgozására (ECRML Explanatory report et al. 1992, 1.).

28 A „Belga nyelvi ügy” az Emberi Jogi Bíróság 1968. július 23-i ítélete. „A vallon illetve flamand nyelvek külön régiót képeztek, és a régió nyelve volt a kizárólagos közigazgatási és állami iskolai oktatás nyelve is. Ez utóbbit tekintették sérelmesnek a flamand régióban élő panaszosok, de tulajdonképpen nem sikerült álláspontjukat az Emberi Jogok Európai Bíróságával elfogadtatni, amely a 2. cikkbe az oktatási nyelv szülői választásának jogát nem tudta beleérteni” (Kovács, 2015. 14.).

29 1957. évi 136. sz. határozat, 1961. évi 285. sz. ajánlás. 


\section{Külïgyi Szemle}

Nemzeti Kisebbségek Védelméről szóló Keretegyezmény

A kelet-közép-európai demokratikus átalakulással párhuzamosan egyre nagyobb politikai igény mutatkozott a nemzeti kisebbségvédelem jogi és politikai kereteinek felülvizsgálatára is. A hidegháború lezárását követő politikai, fegyveres konfliktusok, és a fentebb már említett délszláv háború kíméletlenül irányította rá a nemzetközi szervezetek figyelmét a nemzeti kisebbségek helyzetére, és tudatosította, hogy az etnikai, kulturális és nyelvi sokszínúség társadalmon belüli kezelése nem tû́r halasztást.

A jogi keretek kidolgozásának előkészületei a Miniszteri Bizottságon belül már 1992-ben megindultak, számos javaslat fogalmazódott meg a kisebbségvédelem jövőbeni formáját illetően. A magyar, olasz és jugoszláv hatóságok szorgalmazására a Velencei Bizottság is megvizsgálta a kérdést, és egy kisebbségvédelmi egyezmény szövegezését javasolta ${ }^{30}$. A Miniszteri Bizottságon belül Ausztria az etnikai csopor tok védelméról (FCNM Explanatory report et al. 1995, 2.), a Parlamenti Közgyúlés pedig átfogóbb jelleggel a kisebbségi jogok biztosításáról szóló, az Emberi Jogi Egyezményhez füzendỏ kiegészítő jegyzőkönyv kidolgozását szorgalmazta (PACE Recommendation, 1993, 1201.). Az állam- és kormányfők 1993-as bécsi csúcstalálkozóján ezek fényében arról született döntés, hogy a kisebbségek védelmére egy keretszabályozás kidolgozása szüikséges (Vienna Declaration, 1993).

A bécsi nyilatkozat ezzel egyidőben arról is döntött, hogy a nemzeti kisebbségek egyéni jogait kulturális területen garantáló, az EJEE-t kiegészítő jegyzókönyv szövegezése is szüikséges ${ }^{31}$.

Fenti döntések eredményeképpen a Nemzeti Kisebségek Védelméről szóló Keretegyezmény 1995. február 1-jén aláírásra megnyílt, és három évvel később 1998. február 1-jén hatályba lépett az

30 Explanatory report on the Proposal for a European Convention for the Protection of Minorities by the Venice Commission, 1991, CDL (91) 8. https://www.venice.coe. int/webforms/documents/?pdf=CDL(1991)008-e

31 Ez vezet el a Regionális vagy Kisebbségi Nyelvek Európai Chartájának kidolgozáshoz ETS 148, Strasbourg, 05/11/1992. 
egyezményhez csatlakozó tagállamok vonatkozásában ${ }^{32}$. Keretszabályozás lévén az emberi jogi egyezményhez füzött kiegészítő jegyző könyvnél a nemzeti kisebbségek számára ugyan kevesebb védelmet jelentett, hiszen az EJEE és jegyzőkönyveiben foglaltak megsértése esetén utóbbiak lehetőséget adtak volna a strasbourgi Emberi Jogi Bírósághoz való fordulásra (Szalayné Sándor, 2003. 213.). Mégis hatamas előrelépés abban a tekinteben, hogy az első általános érvé nyű, jogilag kötelező erejű nemzetközi egyezmény a nemzeti kisebbségek jogainak vonatkozásában. A keretegyezmény célja olyan feltételek teremtése a tagállamokban, amelyek hozzájárulnak a nemzeti kisebbségek kultúrájának és identitásának megörzéséhez és fejlesz téséhez. A keretegyezmény rendelkezései szorgalmazzák a törvény előtti egyenlőséget, az identitás, ehhez tartozóan a vallás, a nyelv, a hagyomány és a kuturális örökség védelmét, a gyülekezés, a véleménynyilvánítás, a gondolat-, a lelkiismeret-és a vallásszabadsághoz való jog tiszteletben tartását, a kisebbségi nyelv szabad és beavatkozás nélküli használatát és a kisebbségi nyelven történő tanulás biztosítását. A keretegyezmény emellett azt is indítványozza, hogy a felek szükség esetén törekedjenek a szomszédos államokkal két-és többoldalú egyezmények megkötésére annak érdekében, hogy biztosítsák az érintett nemzeti kisebbségekhez tartozó személyek védelmét (1999. évi XXXIV. törvény) 33 . A keretegyezmény ezen rendelkezése megerősíti a jószomszédi kapcsolatokról és a nemzeti kisebbségek küilönjogainak biztosításáról szóló, szomszédos országokkal kötött alapszerződéseink létjogosultságát és relevanciáját.

32 Ez 1998. február 1-jén 13 tagállamot jelentett: Horvátország, Ciprus, Dánia, Észtor szág, Finnország, Németország, Magyarország, Észak-Macedónia, Moldova, Ro mánia, San Marino, Szlovákia, Spanyolország. Még abban az évben csatlakozott Örményország, Ausztria, Csehország, Olaszország, Lichtenstein, Málta, Oroszország. Szlovénia, Ukrajna és az Egyesült Királyság. Jelenleg az ET 39 tagállama részese az egyezménynek. A mai napig nem csatlakozott Andorra, Belgium, Franciaország. Görögország, Írország, Luxemburg, Monaco és Törökország.

33 1999. évi XXXIV. törvény az Európa Tanács Nemzeti Kisebbségek Védelméröl szóló, Strasbourgban 1995. február 1-jén kelt keretegyezményének kihirdetéséről, https://net.jogtar.hu/jogszabaly?docid=99900034.TV. 


\section{Külïgyi Szemle}

Regionális vagy Kisebbségi Nyelvek Európai Chartája

Bár a Nyelvi Charta már három évvel korábban elfogadásra lerült, 1992. november 5-én aláirásra is megnyílt, a Kisebbségvédelmi Ke retegyezményhez hasonlóan csupán 1998-ban lépett hatályba. Ré szes államainak száma akkor és most is messze elmarad a Kisebb ségvédelmi Keretegyezményétől ${ }^{34}$. Ennek valószínúleg az az oka, ahogy a Nyelvi Charta végrehajtásának felülvizsgálatára létrehozott, független szakértőkből álló bizottság magyar tagja, Kardos Gábor fo galmaz, hogy „a Charta alapkoncepciója (...) az, hogy az európai kultu rális örökség részét képező regionális vagy kisebbségi nyelveket védi. Bevallott célja, hogy eltávolítsa a kulturális örökségvédelem körébe vont kisebbségi nyelvvédelmet a kisebbségi jogok politikai világából, és ilyen módon egyes európai államok számára elfogadhatóbbá váljon. (Azonban) a nyelv politikai ügy... és a kulturális örökségvédelem légies köntösébe öltözve is az marad." (Kardos, 2017. 34.).

A Charta hiába biztosítja a tagállamok számára, hogy csatlako záskor eldönthessék, mely regionális nyelvek vonatkozásában, milyen mértékben és területüik mely részén kötelezik el magukat a hivatalos nyelvektől eltérỏ kisebbségi nyelvet érintỏ általános védelmen felül, a Charta à la carte rendszerének köszönhetően - mivel a regionális vagy kisebbségi nyelvek használóinak „rejtetten és közvetetten” jogokat biztosít (Kardos, G. 2017.33-34-o.) -, félő, hogy a kisebbségi nyelvhasználat körül az utóbbi években amúgy is kialakult feszült politikai légkör nem kedvez az újabb csatlakozásoknak ${ }^{35}$.

34 A Nyelvi Charta 1998. március 1-jén Horvátország. Finnország Magyarország. Lichtenstein. Hollandia, Norvégia vonatkozásában lépett hatályba, abban az évben csupán Svájc csatlakozott hozzá. Ausztria és Szlovénia 2001-ben. Szlovákia 2002-ben, Szerbia és Ukrajna 2006-ban, Románia csak 2008-ban csatlakozott. A balti államok és Oroszország vagy Olaszország, Bulgária a mai napig nem részese, ahogy Belgium, Franciaország, Görögország és Törökország sem. Jelenleg az ET 25 tagállama részese az egyezménynek.

35 Lásd az államnyelv védelméről szóló ukrajnai törvény 2019. április 25-i elfogadását és a Velencei Bizottság ezzel kapcsolatos 2019. december 9-én elfogadott 960/2019 sz. véleményét. 


\section{A Parlamenti Közgyülés szerepe a tagállami kötelezettségvállalások feluilvizsgálatában}

Az Európa Tanács kelet-európai bővítésével párhuzamosan a Parlamenti Közgyűlés egyre jelentősebb szerepet töltött be az újonnan csatlakozók kötelezettégvállalásainak ellenőrzésében, és eleve a monitoringfunkció is egyre hangsúlyosabbá vált a testület tevékenységi körében. A PKGY már a tagfelvételt megelőzően tájékozódott a csatlakozási kérelmet benyújtó állam politikai-intézmé nyi struktúrájáról, és az általános kritériumok mellett sok esetben testre szabva fogalmazta meg elvárásait és véleményét a tagfelvételre vonatkozóan. Tekinetttel arra, hogy Magyarország a volt szovjet blokkból elsőként nyert tagságot az Európa Tancsban 1990ben, a magyar tagfelvételi kérelemről készített 52 oldalas jelentés (PACE report 6288, 1990) alapján kialakított vélemény különösebb elvárásokat már nem fogalmazott meg. Értékelte a különleges meghívottként a PKGY tevékenységében már korábban résztvevő magyar delegációval való addigi együttmúködést, és a részletes jelentésben feltérképezett történelmi, politikai, gazdasági viszonyok, az alkotmányos berendezkedés és addigi reformok, illetve a már aláirt Európa tanácsi egyezmények fényében alkalmasnak nyilvání totta (PACE Opinion 153 (1990). Ezzel ellentétben például az 1995 ben csatlakozási kérelmet benyújtott és 2002-ben felvéltelt nyert Bosznia-Hercegovina esetében a PKGY véleménye hosszan sorolja az ET-normákat, megszabva az előirt egyezményekhez történő csatlakozás elvárt idejét is (tagfelvételt követő egy vagy két éven beluil), valamint azokat a belsô jogalkotási feladatokat, amelyeket szükségesnek ítél az ET-tagság megelőlegezésével párhuzamosan. Természetesen Magyarország és a tetszőlegesen kiválasztott Bosz nia-Hercegovina esete nem teljesen hasonlítható össze, bár a tagság melletti-elleni politikai szempontok nyilván mindkét esetben közrejátszottak. Míg Magyarország esetében nem volt kérdés, hogy az ET előbb-utóbb megnyitja kapuit a volt szovjet blokk országai előtt, és erre a történelmi küldetésre az ET-nek is szüksége volt, 


\section{Külïgyi Szemle}

addig a háborúból éppen kilábaló Bosznia, ahol a külső segítséggel tető alá hozott daytoni megállapodás tulajdonképpen csak az etnikai vérengzéssel járó háborút zárta le, az etnikai ellentéteket nem tudta rendezni ${ }^{36}$, sokkal nagyobb kihívást jelent a békés európai építkezést zászlajára tûzött szervezetnek ${ }^{37}$.

Tulajdonképpen a PKGY monitoringeljárása is a kelet-európai bôvítés vívmányaként értékelhetô. Kezdetben az ET normákkal való megfelelést a PKGY illetékes bizottságai vizsgálták. A PKGY 1993. évi 488 sz. utasítása rendelkezett arról, hogy az új tagállamok vállalásának teljesüléséig a PKGY bizottságok hathavi rendszerességgel számoljanak be a PKGY Bureau-nak. A monitoringeljárás ezt követően fokozatosan intézményesült, bár 1997-ig írásos kérelemre volt szükség formális monitoringeljárás megindításához. Az állandó monitoringbizottság létrehozására 1997-ben került sor (PACE Resolution 1115 (1997)), és innentől kezdve vált automatikussá az új belépők esetében a monitoringeljárás lefolytatása.

Ahogy a szervezet alapításának 50. évfordulója alkalmából - a Miniszteri Bizottság akkori soros magyar elnöksége alatt - 1999 ben kidolgozott dokumentum is hangsúlyozta, az Európa Tanács 1990 utáni nyitott kapuk politikája, a „terápiás tagfeltével” (abbéli meggyőződés, hogy az ET tagság pozitív hatást gyakorol a demokratikus átmenetre) következtében mind a Miniszteri Bizottság, mind a Parlamenti Közgyűlés kialakította saját monitoringeljárását a tagállamok vállalt köteleztettségeinek folyamatos ellenőrzésére. A Miniszteri Bizottság bizalmas párbeszéden alapuló, tematikus kormányközi monitoringja, illetve a PKGY transzparens, országalapú megközelítése egyaránt azt a célt szolgálták, hogy az újonnan csatlakozó tagállamban a kritikus és konstruktív párbeszédnek köszönhetően a demokrácia és emberi jogok tiszteletének lehető legmagasabb szintje alakuljon ki (50 év és 104 ülésszak egy választóvonalak nélkuili, nagyobb Európáért).

\footnotetext{
36 Latal 2019.

37 A Szerző véleménye.
} 


\section{Következtetések}

A XX. század utolsó évtizede, a kelet-közép-európai átalakulás történelmi időszaka kivételes esélyt adott az Európa Tanácsnak, hogy újradefiniálja szerepét a nemzetközi szervezetek versenyében. A maastrichti szerződéssel 1993-ban létrejövő Európai Unió, a budapesti csúcstalálkozó után intézményesülő EBESZ ${ }^{38}$ egyaránt a demokratikus normák és sztenderdek előmozdtásának igényével léptek fel. Az EU-val ellentétben, amely gazdasági együttműködésnek indult, és az EBESZ-szel amely elsősorban biztonsági együittmúködési szervezetként határozta meg magát, komoly hangsúlyt fektetve annak politikai-katonai aspektusaira, az Európa Tanács elsősorban az emberi jogokkal, jogállamisággal, demokráciafejlesztéssel összefüggő normaalkotási és felülvizsgálati tevékenységgel kívánta segíteni tagállamait ${ }^{39}$.

Márpedig az 1990-es években ezek az értékek egyre inkább előtérbe kerültek, hiszen az európai integráció, a kelet-középeurópai államok számára hőn áhított EU-tagság feltételét is, többek között, a szilárd, emberi jogok tiszteletére épülő demokratikus berendezkedés és a stabil jogállami rendszer képezték ${ }^{40}$.

Az Európa Tanács, felmérve ezt a történelmi lehetőséget, gyorsan reagált az új idők új igényeire. Néhány alapvető kritérium teljesítése után - mint az Emberi Jogok Európai Egyezményéhez és felüilvizsgálati mechanizmusához való csatlakozás, ennek részeként a halálbünetetés eltörlése lényegében megelőlegezte a tagságot. Abból indult ki, hogy az új demokráciák többet profitálnak a szervezeten belül rendelkezésre álló, az új igényeknek köszönhetően kialakított, emberi jogok tiszteletét, jogállamiság kiépítését, demokratikus átmenetet segítő mechanizmusokból,

38 Budapest Summit Declaration Towards a Genuine Partnership in a New Era, pp. 12. 1994. december 6. https://www.osce.org/files/f/documents/5/1/39554.pdf.

39 A Szerző véleménye.

40 Outcome Document of the World Summit, 2005, Preamble and in Article 2 of the Treaty on European Union 


\section{Külïgyi Szemle}

mintha kívül maradnának. Ez a szempont látványosan érvényesült az Orosz Föderáció tagfelvételi kérelme körüil kialkult viták során, amikor a tagfelvételt támogatók, köztük a szervezet fôtitkári pozícióját 1994-től betöltő svéd Daniel Tarschys meggyőződéssel képviselte, hogy Európa biztonságát az szolgálja, ha Oroszországot az Európa Tanács a tagjai között tudja (Tarschys, 1997. 4-9.). Tarschys elkötelezettsége nem volt új keletủ, és valóban biztonsági célokat szolgálhatott, hiszen a PKGY raportőreként már 1991-ben, a Szovjetunió megszúnése évében is kifejezte aggodalmát, hogy a Szovjetunió összeomlásával ki gyakorol ellenőrzést a szovjet nukleáris arzenál felett (PACE Recommendation 1991, 1161.).

De a 90-es évek nem csupán az Európa Tanács szempontjából volt meghatározó, a kelet-közép-európai államok is sokat profitáltak az ET-vel való együttmúködésből. Az Európa Tanács tagsága lényegében felkészítette az euroatlanti integráció útján tovébblépni szándékozókat a későbbi uniós tagságra, így számukra lényegében az Unió elószobájának is tekinthető az ET. Jelen tanulmány arra kívánt rávilágítani, hogy a leglényegesebb és az Európa Tanács arculatát napjainkban leginkább meghatározó emberi jogi és jogállamisági sztenderdek, mechanizmusok kialakításásra a kelet-közép-európai demokratikus átalakulás elősegítése és támogatása céljából került sor. Az Európa Tanács intézményi megújulása a 90-es években tehát döntô részben a külső, történelmi kihívásnak és nem a belső reformigényeknek volt köszönhető, így úgy is összegezhetjük, hogy a régió politikai-társadalmi átalakulása idézte elő a szervezet reformját. Ugyanakkor a régió államainak és az Európa Tanácsnak találkoz tak az érdekei abban, hogy új lendületet adjanak a szervezet nor maalkotási tevékenységének olyan területeken is, amely szabályozását éppen az újonnan csatlakozók megjelenése tette szüikségessé. Mind a szervezet, mind az új tagállamok számára gyümölcsözô volt az együttmáködés, hiszen míg az Európa Tanács történelmi küildetését teljesítette, közreműködött a kelet-közép-európai államok euroatlanti integrációval kapcsolatos ambícióinak teljesüilésében. 
Az Európa Tanács Miniszteri Bizottsága második magyar elnök ségének nemzeti kisebbségvédelmi feladatait illetően, az Európa Tanáccsal való további együttmúködésben a jövőben is elsősorban a lehetőségekre célszerû összpontosítani. Bár újabb globális kihívások jelentek meg többek között a migrációval, a kultúrák közöt ti együttéléssel vagy a környezetvédelemmel összefüggésben, a nemzeti kisebbségvédelem kérdését az Európai Bizottság Minority SafePack kezdeményezést elutasító álláspontja fényében szemmel láthatóan továbbra is az Európa Tanácsban szükséges és érdemes új szintekre emelni.

\section{Irodalom}

Barth, Christiane, Bijsmans, Patrick. (2018). The Maastricht Treaty and public debates about European integration: the emergence of a European public sphere?, Journal of Contemporary European Studies, 26:2, 215-231, A letöltés ideje: 2021. március 5. https://www.tandfonline.com/doi/full/10.1080/ $\underline{14782804.2018 .1427558 \text { ? scroll }=\text { top \&needAccess }=\text { true }}$

CM Declaration on the future role of the Council of Europe in Eu ropean construction (1989). Decl(05/05/89). A letöltés ideje: 2021. március 13. https://search.coe.int/cm/pages/result_details. aspx?objectid $=0900001680535 \mathrm{ad} 9$

CM Department for the execution of judgements of the European Court of Human Rights, A letöltés ideje: 2021. március 13. https://www.coe.int/en/ web/execution/presentation-of-the-department

CM Document, 50 years and 104 session for building a greater Europe without dividing lines (1999). A letöltés ideje: 2021. március 13. https://search.coe. int $/ \mathrm{cm} /$ Pages $/$ result_details.aspx?ObjectId $=0900001680531 \mathrm{bd} 9 \#$ globalc ontainer

CMiGuide of the, Procedures and working methods. A letöltés ideje: 2021. március 12. https:/search.coe.int/cm/Pages/result details.aspx?ObjectID =090000168058d922\#_ $\underline{\ln 164}$ 


\section{Külïgyi Szemle}

CMDH Interim Resolution CM/ResDH(2017)429, Execution of the judgment of the European Court of Human Rights, Ilgar Mammadov against Azerbaijan, 5 December 2017. A letöltés ideje: 2021. március 14. https://search.coe.int $/ \mathrm{cm} /$ Pages/result_details.aspx?ObjectID $=090000168076$ flfd

CM Resolution CM(89)82 Restricted on the Final Declaration of the Conference "Democracy through Law" (1989). A letöltés ideje: 2021. március 10. https://rm.coe.int/09000016804b8caa

CMResolution (90) 6 on a Partial Agreement establishing the European Commission for Democracy through Law (1990). A letöltés ideje: 2021. március 12. https:// search.coe.int $/ \mathrm{cm} /$ Pages/result_details.aspx?ObjectID=0900001680535949

CM Resolution (99) 50 on the Council of Europe Commissioner for Human

Rights (1990). A letöltés ideje: 2021. március 5. https://search.coe.int $/ \mathrm{cm} /$ Pages/result_details.aspx?ObjectID $=09000016805 \mathrm{e} 305 \mathrm{a}$

CM Resolution Res(2002)8 on the statute of the European Commission against Racism and (2002). A letöltés ideje: 2021. március 11. https://search.coe.int/ $\mathrm{cm} /$ pages $/$ result_details.aspx?objectid=0900001680973356

CM Resolution Res (2002)3 adopting the revised Statute of the European Commission for Democracy through Law. A letöltés ideje: 2021. március 10. https://www.venice.coe.int/WebForms/pages/?p=01_01_Statute

CM Resolution on Cyprus vs Turkey, Varnava and Others vs Turkey (2018) CM Del/Dec(2021)1398/H46-32. A letöltés ideje: 2021. március 12. https:// search.coe.int/cm/Pages/result_details.aspx?ObjectID=0900001680alb36d

CM Resolution on Five cases against the United Kingdom (2018). CM/ ResDH(2018)46, 7. A letöltés ideje: 2021. március 12. https://search.coe.int/ $\underline{\mathrm{cm} / \text { Pages/result_details.aspx?ObjectID }=09000016808 \text { feca9 }}$

CM Supervision of the execution of judgments of the European Court of Human Rights: procedure and working methods for the Committee of Ministers Human Rights meetings, GR-H(2016)2-final, 30 March 2016, Council of Europe Statute ETS 001. (1949). A letöltés ideje: 2021. március 9. https://www.coe.

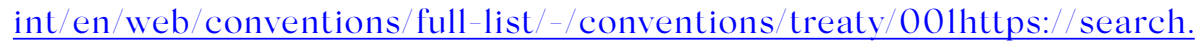
$\underline{\text { coe.int } / \mathrm{cm} / \text { Pages } / \text { result_details.aspx? ObjectId=09000016806303a9 }}$ 
Compilation of ECRI's General Policy recommendations, CRI(2018)16. A letöltés ideje: 2021. március 7. https://rm.coe.int/compilation-of-ecri-s-generalpolicv-recommendations-march-2018/16808b7945

Complete list of the Council of Europe's treaties. A letöltés ideje: 2021. március 13. https://www.coe.int/en/web/conventions/full-list

Council of Europe. The Budapest Declaration for a Greater Europe without dividing lines (1999). A letöltés ideje: 2021. március 12. https://search.coe.

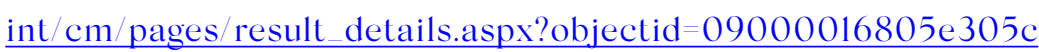

CouncilofEurope Convention for the Protection of Human Rights and Fundamental Freedoms, ETS 005, (1950). A letöltés ideje: 2021. március 13. https:/www.coe.int/en/ $\underline{\text { web/conventions/full-list/-/conventions/rms/0900001680063765 }}$

Council of Euope Convention establishing the CPT and Rules of Procedure, Reference documents. A letöltés ideje: 2021. március 10. https://www.coe. int/en/web/cpt/publications

Council of Europe Founding Fathers. A letöltés ideje: 2021. március 12. https:// www.coe.int/en/web/about-us/founding-fathers

Council of Europe Framework Convention for the Protection of National Minorities ETS 157, Strasbourg, 1995. február 1. A letöltés ideje: 2021. már cius 13. https://www.coe.int/en/web/conventions/full-list/-/conventions/ rms/090000168007edac

Council of Europe Statute ETS 001. (1949). A letöltés ideje: 2021. március 9. https://www.coe.int/en/web/conventions/full-1ist/-/conventions/ treaty/001

Council of Europe Summit, Vienna Declaration and Action Plan (1993). A letöltés ideje: 2021. március 11. https://rm.coe.int/0900001680536c83

Council of Europe Summit, Final Declaration, Second Summit, Strasbourg (1997). A letöltés ideje: 2021. március 10. https://search.coe.int/cm/Pages/ result_details.aspx?ObjectId=090000168058f093

Council of Europe, The Court in Brief, A letöltés ideje: 2021. március 13. https:// www.echr.coe.int/Documents/Court_in_brief_ENG.pdf 


\section{Külïgyi Szemle}

ECRI Country Monitoring, A letöltés ideje: 2021. március 12. https://www. coe.int/en/web/european-commission-against-racism-and-intolerance/ countrv-monitoring

ECRI Standards, A letöltés ideje: 2021. március 12. https://rm.coe. int/ecri-european-commission-against-racism-and-intolerancebrochure $16808 \mathrm{c} 6 \mathrm{e} 42$

ECRI Internal Rules of Procedure. A letöltés ideje: 2021. március 12. https:// rm.coe.int/internal-rules-of-procedure-of-ecri-adopted-by-ecri-on-20march-2003-a/16808b86d0

Európa Tanács Egyezménye a Kínzás és az embertelen vagy megalázó bün tetések vagy bánásmód megelőzésérôl ETS 126. (1987). A letöltés ideje: 2021. március 13. https://rm.coe.int/16806dbb2c

Emberi Jogok Európa Egyezménye, ETS 005, (1950). A letöltés ideje: 2021. március 11. https://www.echr.coe.int/documents/convention_hun.pdf

European Charler for Regional or Minorily Languages ETS 148. (1992). A letöltés ideje: 2021. március 11. https://www.coe.int/en/web/conventions/full-list/-/ conventions/rms/0900001680695175

Explanatory report to the European Charter for Regional or Minority Languages (1992). A letöltés ideje: 2021. március 11. https://rm.coe.int/ CoERMPublicCommonSearchServices/DisplavDCTMContent?document $\underline{\mathrm{Id}=09000016800 \mathrm{cb5} 5}$

Explanatory report to the Framework Convention for the Protection of National Minorities

Strasbourg, 1995. február 1. A letöltés ideje: 2021. március 11. https://rm.coe. int/CoERMPublicCommonSearchServices/DisplayDCTMContent?docu mentId=09000016800cb5eb95

Explanatory report on the Proposal for a European Convention for the Protection of Minorities by the Venice Commission, (1991). CDL (91) 8. A letöltés ideje: 2021. március 12. https://www.venice.coe.int/webforms/ documents $/$ ?pdf $=$ CDL(1991)008-e

Gazdag, Ferenc, Kovács, Péter. (1999). Az Európa Tanács 1949-1999, SVKI. 
Herczeg, Géza. (1998). Kelet-Közép-Európa mint történelmi régió. Magyar Szemle, Új Folyam VII. 9-10. szám. Letöltve: 2021. március 12. http://www. magvarszemle.hu/cikk/19980901_kelet-kozep-europa_mint_tortenelmi regio

Hlavac, Marek (2010): Less Than a state, more than an international organization: The Sui generis nature of the European Union. Munich Personal RePEc Archive PAPER. A letöltés ideje: 2021. március 12. https://mpra.ub.unimuenchen.de/id/eprint/27179

Hoffmann-Riem, Wolfganf (2014). The Venice Commission of the Council of Europe - Standards and Impact. European Journal of International Law 25(2): 579-597 July 2014. A letöltés ideje: 2021. március 12. https://www.venice. coe.int/files/articles/Hoffmann-Riem_Venice-Commission_Standards.pdf

Joris, Tony, Vandenberghe, Jan. (2008). The Council of Europe and the European Union: natural partners or uneasy bedfellows? Columbia Journal of Europe an Law, 15(1), 1-41. A letöltés ideje: 2021. március 11. https://heinonline.org/ $\underline{\text { HOL} / \text { LandingPage?handle }=\text { hein.journals/coljeull5\&div=4\&id=\&page }}$

Kardos, Gábor (2017). Mérlegen a Nyelvi Charla, Kisebbségi Szem le 2. évf. 3.sz. (2017.). A letöltés ideje: 2021. március 13. http://epa.niif.

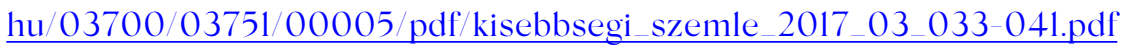

Kende Tamás (1995). Palánkai Tibor (1995). Az európai inlegráció gazda ságlana. Aula Kiadó, Budapesti Közgazdaságtudományi Egyetem. pp. 124-143.

Kovács, Péter (2015). Kisebbségvédelem az Emberi Jogok Európai Birósá ga joggyakorlatában, KJI, pp. 14. A letöltés ideje: 2021. március 13. https://www.kji.hu/wp-content/uploads/2016/06/Ko\%cc\%88nvvKissebbs\%c3\%a9gv\%c3\%a9delem.pdf

Latal, Srecko (2019). Serb Leader's War drums Stir New Fears in Bosnia. Balkan Insight. A letöltés ideje: 2021. március 14. https://balkaninsight. com/2019/04/16/serb-leaders-war-drums-stir-new-fears-in-bosnia/

Mandate of the Commissioner for Human Rights. A letöltés ideje: 2021. március 13. https://www.coe.int/en/web/commissioner/mandate 


\section{Külïgyi Szemle}

Mandate of the European Commission against Racism and Intolerance. A letöltés ideje: 2021. március 13. https://www.coe.int/en/web/european-commissionagainst-racism-and-intolerance/ecri-s-mandate

Mezei Géza (1999). Gazdag Ferenc, Kovács Péter (1999). Az Európa Tanács intézmé nyei és müködése - belülról nézve. Az Európa Tanács 1949-1999, SVKI, pp. 49-63.

Official Journal of the European Union. (1992). Treaty on European Union. A le töltés ideje: 2021. március 7. https://eur-lex.europa.eu/legal-content/HU/ TXT/?uri=CELEX:11992M/TXT

Official Journal of the European Union (2012). Consolidated version of the Treaty on European Union. A letöltés ideje: 2021. március 13. https://eur-lex.europa.eu/ resource.html?uri=cellar:2bfl40bf-a3f8-4ab2-b506-fd71826e6da6.0023.02 DOC $1 \&$ format $=$ PDF

Official Journal of the European Communities. (1987) Letter from Jacques Delors to Marcelino Oreja. A letöltés ideje: 2021. március 10. https://www.cvce.eu/en/ obj/letter_from_jacques_delors_to_marcelino_oreja_brussels_16_june_1987en-07dla62d-3324-42b7-8clb-el5b486alde3.html

Resolution adopted by the UN General Assembly. (2005) Outcome Document of the World Summit. A letöltés ideje: 2021. február 5. https://www.refworld.org/ docid/44168a910.html

PACE Recommendation 38 (1949) Human rights and fundamental freedoms. A letöltés ideje: 2021. március 11. http://assemblv.coe.int/nw/xml/XRef/XrefDocDetails-EN.asp?FileID $=14035$ \&lang=EN

PACE Doc. 108, (1949) Measures for the fulfiment of the declared aim of the Council of Europe in accordance with Article 1 of the Statute in regard to the safeguard and further realisation of Human Rights and fundamental freedoms Conclusionsl Parliamentary Assembly, retrieved on 04/08/2020: http://assembly.coe.int/nw/xml/XRef/Xref-DocDetails-EN. asp?FileID $=51$ \&lang $=\mathrm{EN}$

PACE Recommendation 234 (1960)1 Second Protocol to the Convention on Human Rights. A letöltés ideje: 2021. március 13. http://assembly.coe.int/ nw/xml/XRef/Xref-DocDetails-en.asp?FileId=14271 
PACE Recommendation 285 (1961) Rights of national minorities. A letöltés ideje: 2021. március 13. https://pace.coe.int/en/files/14322

PACE Recommendation 1124 (1990) on Relations with the countries of Central and Eastern Europe (General policy of the Council of Europe). A letöltés ideje: 2021. március 13. https://pace.coe.int/en/files/15158

PACE Opinion 153 (1990). Application by Hungary for membership of the Council of Europe, A letöltés ideje: 2021. március 13. https://pace.coe.int/pdf/62a40 a46439a09c077477d2fe05998f331aa57963326667a8259ffe25682ae848 428febal2/opinion\%20153.pdf

PACE Order No. 488 (1993) on Honouring of commitments entered into by new member states. A letöltés ideje: 2021. március 13. https://pace.coe.int/en/ $\underline{\text { files/13691 }}$

PACE Resolution 1115 (1997) on Setting up of an Assembly committee on the honouring of obligations and commitments by member states of the Council of Europe (Monitoring Committee). A letöltés ideje: 2021. március 11. http://assembly.coe.int/nw/xml/XRef/Xref-XML2HTML-en. asp?fileid $=16526$

PACE Recommendation 1161 (1991) on the Crisis in the Soviet Union. A letöltés ideje: 2021. március 13. https://pace.coe.int/en/files/15195/html

PACE Recommendation 1201 (1993)1 Additional protocol on the rights of minorities to the European Convention on Human Rights. A letöltés ideje: 2021. március 13. http://assemblv.coe.int/nw/xml/XRef/Xref-DocDetailsen.asp?FileId $=15235$

PACE Recommendation 1438 (2000). A letöltés ideje: 2021. február 15. https:// pace.coe.int/en/files/16765

PACE report. Doc. 6288, 1990. szeptember 21. Report on Hungary's application for membership of the Council of Europe. A letöltés ideje: 2021. március 13. https://assemblv.coe.int/Documents/WorkingDoes/1990/EDOC6288.pdf

Press release of ECIIIR on Judgment in the case of Cyprus v.Turkey (2001). A letöltés ideje: 2021. március 13. https://hudoc.echr.coe.int/eng-press\# \{\%22itemid\%22:[\%22003-68489-68957\%22]\} 


\section{Külïgyi Szemle}

PACE Rules of Procedure (1999). A letöltés ideje: 2021. március 10. http://assemblv.coe.int/nw/xml/RoP/RoP-XML2HTML-EN.asp?id=EN_CEGEIFJD

Prolocol No. 6 to the European Convention on Human Rights concerning the Abolition of the Death Penalty, ETS 114, (1983). A letöltés ideje: 2021. március 10. https:/www.coe.int/en/web/conventions/full-list/-/ conventions/treaty/114

Protocol No. 13 to the Convention for the Protection of Human Rights and Fundamental Freedoms, concerning the abolition of the death penalty in all circumstances, ETS 187 (2002). A letöltés ideje: 2021. március 10. https:// www.coe.int/en/web/conventions/full-list/-/conventions/treaty/187

Protocol No. 14 to the Convention for the Protection of Human Rights and Fundamental Freedoms, amending the control system of the Convention CETS 194 (2004). A letöltés ideje: 2021. március 13. https://www.coe.int/ en/web/conventions/full-list/-/conventions/rms/0900001680083711

Protocol No. 15 amending the Convention for the Protection of Human Rights and Fundamental Freedoms CETS 213 (2013). A letöltés ideje: 2021. március 10. https://www.coe.int/en/web/conventions/full-list/-/conventions/treaty/213

Protoco/No. 16 to the Convention for the Protection of Human Rights and Fundamental Freedoms CETS 214 (2013). A letöltés ideje: 2021. március 10. https://www.coe. int/en/web/conventions/full-list/-/conventions/rms/0900001680084832

Schnutz Dürr, R. (2010). The Venice Commission. In International Encyclopaedia of Laws, Intergovernmental Organizations, Supplement 39 Council of Europe pp. 349-382, ed. by Prof. Dr. R. Blanplain, Wolters Kluwer Law\&Business. A letöltés ideje: 2021. március 9. https://www. venice.coe.int/files/articles/Durr_Venice_Commission.pdf

Szalayné Sándor, Erzsébet (2003). A kisebbségvédelem nemzetközi jogi intézményrendszere a 20. században. pp. 213. Kisebbségi monográfiák III. Gondolat Kiadói Kör, MTA-Kisebbségtudományi Intézet, Budapest.

Tarschys, Daniel (1997). The Council of Europe: strengthening European security by civilian means, pp. 4-9. NATO Review. A letöltés ideje: 2021. március 13. https:/www.nato.int/docu/review/1997/9701-1.htm 
Treaty establishing the European Economic Community (1957). A letöltés ideje: 2021. március 13. https://www.cvce.eu/obj/treatv_establishing_the_ european_economic_community_rome_25_march_1957-en-cca6ba28Obf3-4ce6-8a76-6b0b3252696e.html

Treaty of Paris setting up the European Coal and Steel Community (1951). A letöltés ideje: 2021. március 13. https://www.cvce.eu/obj/treaty_ establishing_the_european_coal_and_steel_community_paris_18_ april_1951-en-11a21305-941e-49d7-al71-ed5be548cd58.html

Venice Commission. Annual report of activities 2019, CDL-RA(2019)001-e. A letöltés ideje: 2021. március 13. https://www.venice.coe.int/webforms/ documents $/$ ? pdf $=$ CDL - RA(2019)OO1-e

Venice Commission Proposal for an European Convention for the Protection of Minorities, CDL(1991)007-e. A letöltés ideje: 2021. március 13. https:// www.venice.coe.int/webforms/documents/?pdf=CDL(1991)007-e 